\title{
The oophorectomy effect on Walker 256 tumor inoculated into the vagina and uterine cervix of female rats ${ }^{1}$
}

\author{
Efeito da ooforectomia no tumor de Walker 256 inoculado em vagina e colo de útero de ratos \\ fêmeas
}

\author{
Nara Macedo Botelho BritoI, Rita de Kássia Vidigal CarvalhoII, Lia Tavares de Moura Brasil Matos" Rodolfo Costa Lobato"I, \\ Rosângela Baía BritoIII
}

${ }^{I} \mathrm{PhD}$, Associate Professor, Department of Specialized Health, UEPA, Para, Brazil.

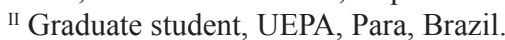

III MD, Pathologist, UEPA, Para, Brazil.

\begin{abstract}
Purpose: Verify the effect of oophorectomy on the evolution of the Walker 256 tumor inoculated into the vagina and cervix of female rats. Methods: Ten Wistar, female rats were used, distributed into two groups with 05 animals each: Tumor group (TG): Rats inoculated with Walker 256 tumor; Oophorectomy group (OG): oophorectomized rats inoculated with Walker 256 tumor. The day before the tumor vaginal inoculation, acetic acid was inoculated into the vaginas of both groups of rats; the following day, the vaginal walls were scarified with an endocervix brush, and then Walker 256 tumor was inoculated. After 12 days, the tumor was removed together with the vagina and uterine horns for macro and microscopic analyses. The data were submitted to statistical analyses. Results: There was no statistical difference between the two groups; however it was observed that the behavior of tumor growth on the OG group presented greater invasion, compromising the uterine horns. Conclusion: The results of the study on the GO group presented a macroscopic behavior different from the TG group, however, both of them presented similar development in terms of tumor mass.
\end{abstract}

Keywords: Ovariectomy. Cervix Uteri. Vagina. Carcinoma 256, Walker. Rats.

\section{RESUMO}

Objetivo: Verificar o efeito da ooforectomia à inoculação do tumor de Walker 256 em vagina e colo de útero de ratas. Métodos: Foram utilizadas 10 ratas Wistar, fêmeas, virgens, adultas, distribuídas em dois grupos de estudo com 05 animais cada: grupo tumor (GT): ratas inoculadas com tumor de Walker 256, e grupo Ooforectomia (GO): ratas ooforectomizadas e inoculadas com tumor de Walker 256. No dia anterior à inoculação vaginal do tumor, foram inoculados $0,3 \mathrm{ml}$ de ácido acético na vagina das ratas de ambos os grupos; no dia seguinte, foi realizada a escarificação da parede vaginal com uma escova de endocérvice e inoculado tumor de Walker 256. Após 12 dias, foi removido o tumor em bloco com vagina e cornos uterinos para análise macro e microscópica. Os dados foram submetidos à análise estatística. Resultados: Não houve diferença estatística entre os dois grupos; no entanto, notou-se que o comportamento de crescimento do tumor no grupo GO apresentou maior invasividade em extensão, comprometendo cornos uterinos. Conclusão: Observou-se que o grupo GO apresentou comportamento macroscópico diferente ao grupo GT, no entanto, em termos totais de massa tumoral ambos apresentam desenvolvimento similar.

Descritores: Ovariectomia. Colo do Útero. Vagina. Carcinoma 256 Walker. Rats.

${ }^{1}$ Research performed at Laboratory of Experimental Surgery, State University of Para (UEPA), Brazil.

\section{Introduction}

Walker 256 tumor induction model has been widely described in the literature, showing high take rate and easy handling during laboratory anlysis ${ }^{1}$. The model was discovered in 1928, when George Walker, in his laboratory at Johns Hopkins University Medical School, noticed in mammal gland of an albino, pregnant, female rat a tumor mass, which according to his own description, receded during lactation and broke out anew shortly after ${ }^{2}$.

This tumor has aroused plenty of interest as an experimental model for the tumor biology study ${ }^{1,3}$. It was verified that growth and the time elapsed between inoculation and the surge of the tumor was in direct proportion to the number of intramuscularly injected cells ${ }^{1,4}$.

There are several models described in the literature, most 
of them with $100 \%$ of take rate regarding the sites where they have been implanted ${ }^{1,2,3,5}$. One assumes that it develops better in male than in female rats, considering that is due to hormonal influence, however there are no solid evidences of sexual hormones participation in its evolution 6 .

There are several studies on the relationship between the evolution of breast neoplasia and exposition to estradiol. Besides, there are no reports about the influence of ovarian hormone supply interruption in the evolution of gynecological tumors during some procedures, such as oophorectomy ${ }^{7}$.

It is known that estrogen boosts cell proliferation, induces the formation of receptors and increases mammary epithelium and stroma cells DNA synthesis ${ }^{8}$, thus leading to the assumption that the risk of breast cancer would be minimized in women with reduced exposure to stradiol due to a reduced breast cell proliferation ${ }^{9}$.

In estrogen responsive tissues, including normal and neoplastic mammary epithelium, the regulation of proliferation by steroids and steroid antagonists occur for specific action on the cells at their $\mathrm{G}_{1}$ phase of the cell cycle ${ }^{10}$. That would be the aim of the study on cell proliferation.

It is also well established the mitogenic effect of estrogens on mammary epithelial cells ${ }^{11}$. On the other hand, its correlation with Walker Tumor, which originates from mammary cells, continues to be discussed, as well as the influence of interruption in production of sexual hormones on its growth and evolution. Thus, it is viable to verify the influence of oophorectomy in the evolution of experimentally induced Walker tumor into the vagina and cervix of female rats.

\section{Methods}

The handling of all animals used during the research were done according to Brazilian regulations in force for animal vivisection and the norms of the Brazilian College for Animal Experimentation, and the research bill approved by the Ethical Committee on Research of the State University of Pará.

Ten virgin, female rats (Rattus norvegicus albinus) of Wistar lineage were used, weighing between $200-250 \mathrm{~g}$, provided by Instituto Evandro Chagas vivarium, and adapted to the State University of Pará Experimental Surgery Laboratory, 15 days prior to the experiment. The animals were kept under controlled environment, with water and food ad libitum.

The animals were distributed randomly into two study groups, 05 animals each.

* The Oophorectomy Group (OG): Female rats subjected to oophorectomy which, after inspection for anoestrus, were submitted to Walker tumor inoculation.

* Tumor Group (TG): Female rats with Walker 256 tumor and not oophorectomized.

\section{Procedures}

All OG group animals were anesthetized with inhaled ethyl ether, manually depilated and then had a $2 \mathrm{~cm}$ transverse laparotomy performed to reach the ovaries, which were connected both proximal and distal at $1 \mathrm{~cm}$ distance from the cervix and then sectioned (Figure 1). The laparorrhaphy was performed with 3-0 cotton. After 21 days, the female rats were subjected to exfoliative vaginal cytology, then, the content was deposited on the surface of a glass dish which was immersed into absolute alcohol for fixation. The glass dishes were stained with the Shorr method $^{12}$ and then analyzed using an optical microspcope in order to characterize the estral cycle, to confirm anoestrus.

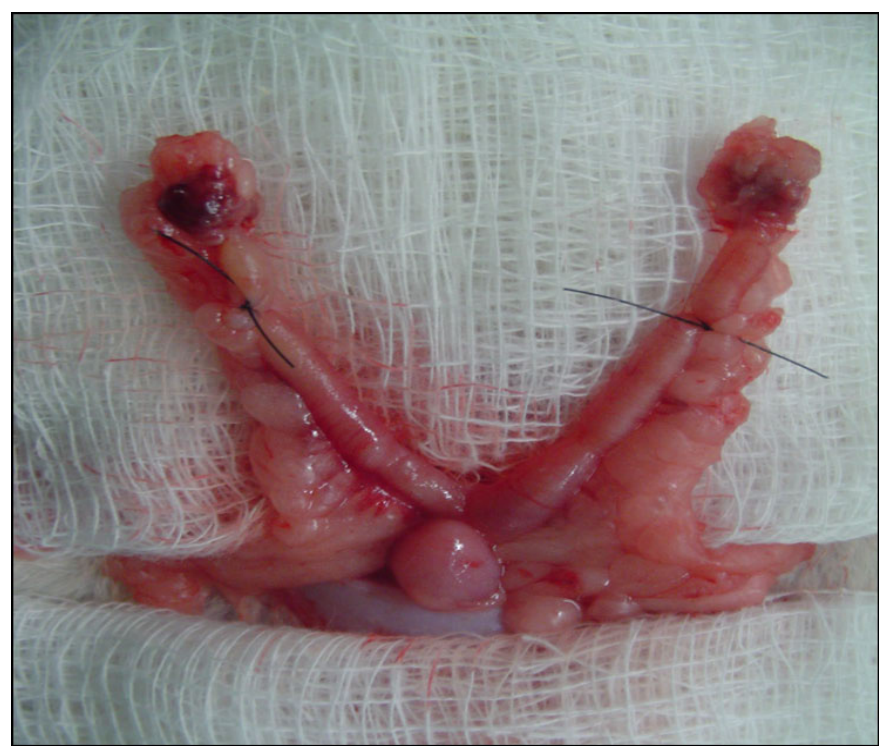

FIGURE 1 - Aspect of connected uterine horn

A day before the tumor inoculation, $0.3 \mathrm{ml}$ of acetic acid at $10 \%$ was introduced in the vaginal canal of $\mathrm{TG}$ and $\mathrm{OG}$ rats, being the animals anesthetized with ethyl ether, to generate inflammation of the vaginal mucosa.

When Walker 256 tumor was inoculated, both group of rats were anesthetized with inhaled ethyl ether, and then, performed scarification on the vaginal mucosa using an endocervix brush, following description by Brito et al. ${ }^{13}$ (Figure 2).

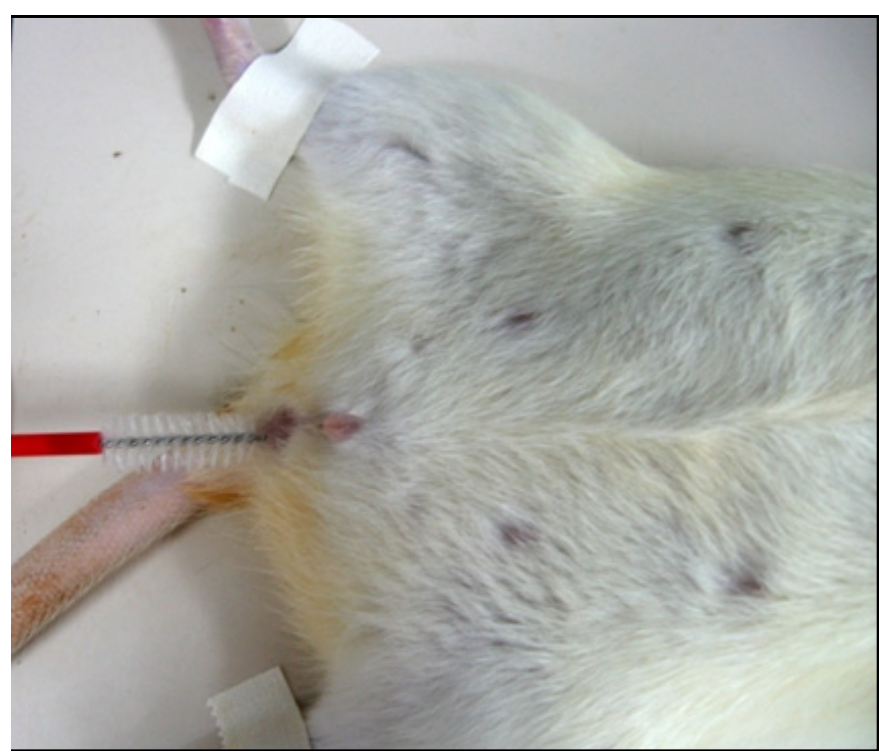

FIGURE 2 - Vaginal scarification 
Walker 256 tumor, extracted from the paw of a sick animal, was prepared according to description in the literature and inoculated into the rat vaginal canal, using $0.3 \mathrm{ml}$ of tumor solution at a $4 \times 10^{6}$ cell concentration.

Twelve days later, euthanasia was performed in the groups through inhalation of lethal ethyl ether. The rats were weighed and the tumor removed in a block containing the vagina and the uterine horns for analysis. The items were weighed in a precision scale; its volume measured through water displacement in a handcrafted pletismometer, and calculated the relation between tumor weigh and the rat final weight, as well as the macroscopic analysis of the pieces.

The results were recorded in protocol and submitted to statistical analysis using the ANOVA test, from the Bioestat version 4.0 software, fixed at 0.05 or $5 \%$ as the level of rejection of null hypothesis, indicating with an asterisk the significant values.

\section{Results}

TABLE 1 - Weight of extracted tumor mass

\begin{tabular}{ccc}
\hline & Tumor Group & Oophorectomy Group \\
\hline R1 & 3,94 & 4,82 \\
R2 & 7,65 & 7,124 \\
R3 & 4,91 & 3,9 \\
R4 & 6,3 & 4,283 \\
R5 & 5,25 & 6,388 \\
\hline
\end{tabular}

Source: research protocol

TABLE 2 - Volume of tumor mass extracted from female rats

\begin{tabular}{ccc}
\hline & Tumor Group & Oophorectomy Group \\
\hline R1 & 4 & 3 \\
R2 & 7 & 7,5 \\
R3 & 3,5 & 4 \\
R4 & 6 & 2,5 \\
R5 & 5 & 5 \\
\hline
\end{tabular}

Source: research protocol

TABLE 3 - Percentage of tumor weight relative to rat body masses

\begin{tabular}{ccc}
\hline & Tumor Group & Oophorectomy Group \\
\hline R1 & 1,82 & 2,22 \\
R2 & 3,31 & 3,19 \\
R3 & 2,28 & 1,79 \\
R4 & 2,78 & 2,36 \\
R5 & 3,22 & 2,97 \\
\hline
\end{tabular}

Source: research protocol
TABLE 4 - Percentage of tumor volume relative to body mass

\begin{tabular}{ccc}
\hline & Tumor Group & Oophorectomy Group \\
\hline R1 & 1,85 & 1,38 \\
R2 & 3,03 & 3,36 \\
R3 & 1,62 & 1,84 \\
R4 & 2,65 & 1,38 \\
R5 & 2,8 & 2,33 \\
\hline
\end{tabular}

Source: research protocol

Macroscopically, in terms of total tumor mass, both groups showed similar development (Figure 3).

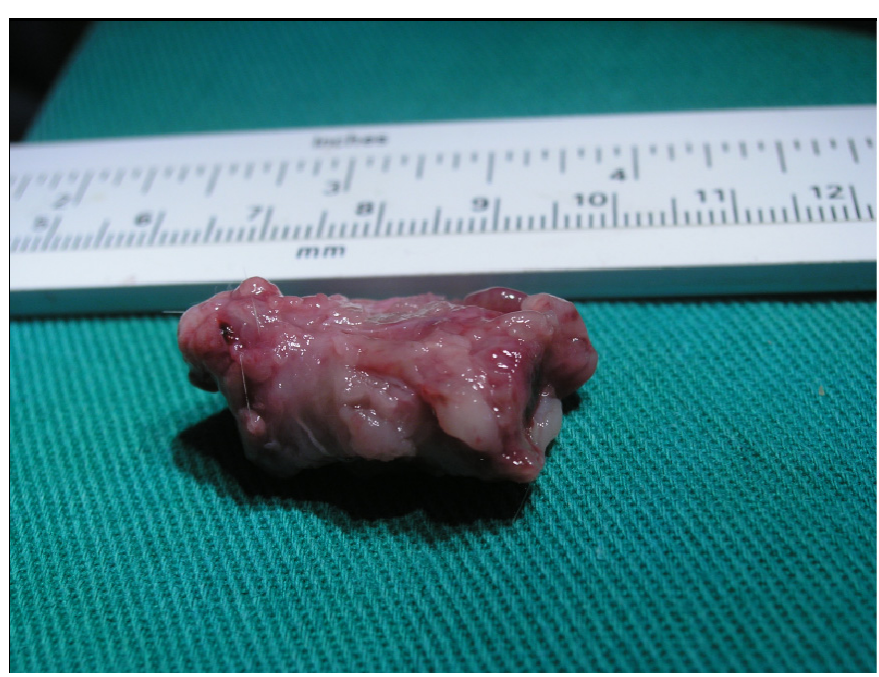

FIGURE 3 - Macroscopically aspect in both groups

Microscopically, there was a compromising of the entire wall of the organs affected by neoplasia on both groups, with loss of tissue normal characteristics. Besides, the cell lineage showed itself undifferentiated, similar to a small cell tumor (Figure 4).

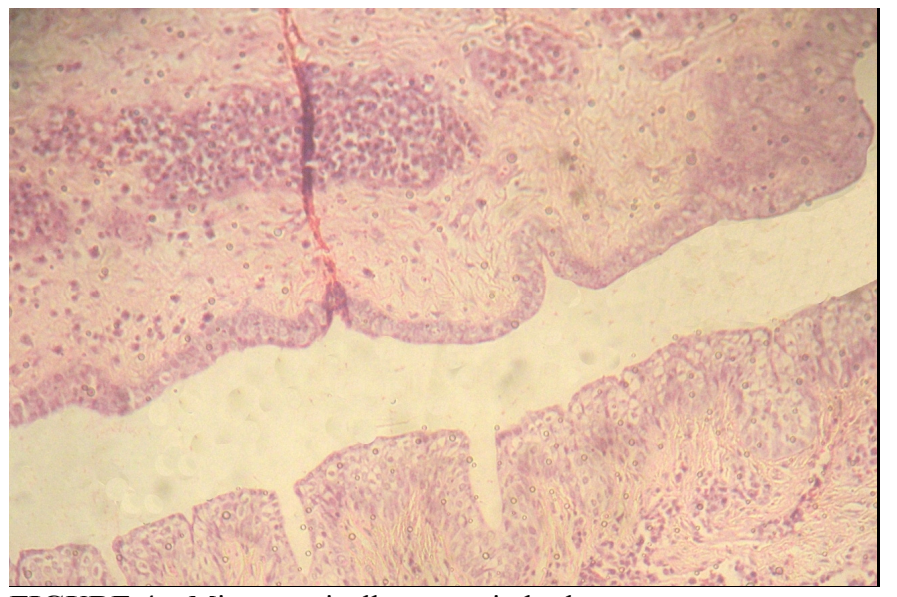

FIGURE 4 - Microscopically aspect in both groups 


\section{Discussion}

It was found that Walker 256 tumors develop better in male than on female rats, a fact credited to hormonal influence; however there are no solid evidences of participation of sexual hormones in its evolution 6 .

It was noticed that the OG group presented a macroscopic behavior different from TG, presenting higher invasion in extension, compromising the uterine horns, while the TG group remained confined to the cervix-vaginal area of growth, different from the OG group; however, in terms of total tumor mass, both showed similar development.

That may be due to the fact that scarified tissues promote an increase on the take rate of the tumor ${ }^{14}$; thus, the presence of strings used for wiring of uterine horns could have influenced the extension of tumor all the way to the uterine horns.

Besides, the Walker tumor has had its cell characteristic changed, with successive inoculation throughout the time - in the past it was considered an adenocarcinoma, now an undifferentiated tumor $^{1,6}$. Successive inoculations may also have changed the tumor genome, causing its estrogenic receptors to disappear, no longer being hormone- dependent.

On this study, the inoculated tumor has presented itself histologically undifferentiated and similar to a small cell tumor. Besides, the inoculation site did not affect the tumor characteristics, because both in vagina and cervix, the cells presented themselves the same way, with replacement of normal cell architecture by neoplastic.

\section{Conclusion}

There was no difference between growth from the group without oophorectomy and the oophorectomized one.

\section{References}

1 - Moraes SP, Cunha A, Reis Neto JA, Barbosa H, Roncolatto CAP, Duarte RF. Modelo experimental de tumor de Walker. Acta Cir Bras. 2000;15(4): 252-6.

2 - Hard GC. Experimental models for the sequential analysis of chemical induced renal carcinogenesis. Toxicol Pathol. 1986;14:112-22.

3 - Earl WR. A study of the Walker rat mammary carcinoma 256: in vivo and in vitro. Am J Cancer. 1935;24:566-612

4 - Schrec R, Avery RC. Histological observation on transplantable rat and rabbit tumors cultivated in the chorio-allantoic membrane of chick embryos, with special reference to the walker rat tumor 256. Am J Pathol. 1937;13:41-5.

5 - Caldirola L, Dei Poli M, Biglani S. Sullo svilupp del tumore di walker nella cute e nel tessuto sutto: cutaneo del ratto-nota I. Minerva Chir. 1968;23:51-5. 6 - Moraes SP, Cunha A, Reis Neto JA, Barbosa H, Roncolatto CAP, Duarte RF. Modelo experimental de tumor de Walker. Acta Cir Bras. 2000;15(4):237-42.

7 - Hargreaves DF, Knox F, Swindell R, Potten CS, Bundred NJ Epithelial proliferation and hormone receptor status in the normal post-menopausal breast and the effects of hormone replacement therapy. Br J Cancer. 1998;78:945-9.

8 - Moraes MO, Fonteles MC, Moraes MEA, Machado MIL, Matos FJA. Screening for anticancer activity of plants from the northeast of Brazil. Fitoterapia. 1997;68(3):235-40.

9 - Vicelli JT, Gurgel MSC, Alvarenga M. Histologia mamária após uso de esteróides sexuais - estudo em ratas. Rev Assoc Med Bras. 2006;52(5):369-74.

10 - Sutherland RL, Hamilton JA, Sweeney KJ, Watts CK, Musgrove EA. Expression and regulation of cyclin genes in breast cancer. Acta Oncol. 1995;34:651-6.

11 - Söderqvist G. Effects of sex steroids on proliferation in normal mammary tissue. Ann Med 1998;30:511-24.

12 - Shorr E. A new technique for staining vaginal smears: III, a single differential stain. Science. 1941;94(2449):545-6.

13 - Brito NBM, Brito MVH, Carvalho RKV, Matos LTMB, Veloso TS, Vasconcelos DM, Brito RB. Experimental inoculation model of Walker 256 carcinoma into vagina and cervix uteri of female rats. Acta Cir Bras. 2007;22(6):495-8.

14 - Oliveira PFM, Henriques IA, Rodrigues-Filho F, Almeida PRC, Moraes MO. Estabelecimento de um modelo de tumor experimental pela inoculação do tumor de Walker em estômago de rato. Acta Cir Bras. 1998;13(4):243-8.

Conflict of interest: none Financial source: none

\section{Correspondence:}

Nara Macedo Botelho Brito

Travessa Padre Eutíquio, 264/1101

66033-000 Belem - PA Brazil

narabrito@amazon.com.br

Received: August 05, 2008

Review: October 09, 2008

Accepted: November 10, 2008

\section{How to cite this article}

Brito NMB, Carvalho RKV, Matos LTMB, Lobato RC, Brito RB. The oophorectomy effect on Walker 256 tumor inoculated into the vagina and uterine cervix of female rats. Acta Cir Bras. [serial on the Internet] 2009 Jan-Feb;24(1). Available from URL: http://www.scielo.br/acb 